\title{
Progressive Collapse of High-Rise Buildings from Fire
}

\author{
Valerii Pershakov ${ }^{1}$, Andrii Bieliatynskyi ${ }^{1}$, Ivanna Popovych ${ }^{1, *}$, Katerina Lysnytska $^{1}$ and \\ Vladimir Krasheninnikov ${ }^{2}$ \\ ${ }^{1}$ National Aviation University, 03058 Kosmonavta Komarova, 1, Kyiv, Ukraine \\ ${ }^{2}$ Peter the Great St. Petersburg Polytechnic University, 195251 Politekhnicheskaya st., 29, Saint- \\ Petersburg, Russia
}

\begin{abstract}
Considers ensuring the stability of structures of high-rise buildings against progressive collapse due to fire, proposed measures to ensure the stability of high-rise buildings due to progressive collapse. The analysis of large fires in high-rise buildings with progressive collapse and review of the literature on the issue of progressive collapse. The analysis of the Ukrainian normative documents on progressive collapse resistance.
\end{abstract}

\section{Introduction}

The worldwide and also Ukraine problem of ensuring the stability of structures of high-rise buildings against progressive collapse as a result of fire is becoming more urgent because, leads to very serious consequences. Wear and tear of fixed assets of the country, increasing the rate and density of construction in urban areas, an increase in recent years, the number of terrorist acts (bombings, arson, etc.) - all this creates the potential value of progressive collapse.

Since the world's terrorist attack in the United States on September 11 examines projects for the construction of high-rise buildings are able to withstand explosions and fires. The questions of limiting the height of high-rise buildings, increasing the number of routes for evacuation, tightening security zone requirements. Advances maintenance of elevators performance requirements during a time of emergency situations, including fires.

\section{Literature review}

Designing of residential buildings is carried out taking into account the factors that caused emergencies, including fire. The structural system of residential buildings must be designed so as to ensure its overall stability during emergency Norm local destructive loads on the individual load-bearing structures, at least for the time required for evacuation of people (the explosions of various types, fires, falling heavy objects, impact of heavy vehicles, etc.) [1-3].

\footnotetext{
*Corresponding author : popovich_ivanna@mail.ru
} 
As a result of fires in high-rise buildings with the appropriate conclusions, and the reaction of the authorities of different countries, their effects have been amended in the regulations [1-6], due to the fact that the fires in high-rise buildings, more traumatic and lead to more damage than normal fires buildings. A fire in a building higher than 25 floors, is 3-4 times more victims than the 9-16-storey building [7 - 9].

So there are special requirements for fire resistance of structures, elevators for firefighters to escape routes to the backup power supply [10 - 27]. To estimate the necessary measures to limit the spread of fire through the building should be a closer look at the fires that have influenced the formation of the regulatory requirements for fire resistance of structures and putting out fires in high rise buildings.

For example, a fire in the 62-storey building in Los Angeles in 1988, despite the fact that virtually the entire area of the building was equipped with sprinklers, the water in case of fire has been given. Only through the optimum fire protection of load-bearing elements, steel skyscraper construction withstood a three-hour exposure to a flame. On fire 64 firefighters were involved calculation, which is half of the city fire forces [28].

Fire-fighting system has not worked well, and a fire in 2004 in the 56-storey skyscraper in Caracas government. The building was completely equipped with sprinkler, but it was defective. 2 hours after the start of the fire, the fire spread to the roof, covering the floors with the upper 34 to 56 floors, and lasted more than 17 hours [29].

A fire in a 37-storey high-rise building in Chicago in 2003. The fire started on the 12th floor. The building was not protected by sprinkler system and fire spread beyond the room, because the walls of the corridor were not implemented on the entire height of the floor. Hot flue gases also got into the ventilation system of the corridor. As the doors of floors in the stairwell was in order to protect the security locked from the stairs, the people who came into the stairwell, they could not get away with it. As a result, six people were killed there, locked up 12 floors. The subsequent fire analysis showed that if the doors are not blocked by the stairs, people would not have died. Also, if the building was equipped with protective materials, flue gases would not be so hot and would not receive such an extension [29].

In Odessa, in 2015 he lit paneling on the upper floors of the unfinished buildings of the complex "Arcadia". the fire quickly spread to the first from the upper floors. Burned paneling. The fire was extinguished by two tall ladders 30 and 50 meters. But the problem was that the sleeves did not have enough pressure, and does not provide internal fire extinguishing system in the building (Fig. 1a). [30]. Another complicating factor in extinguishing fires in high-rise buildings, and not only in them, is not sufficiently fast arrival of fire units. This is not always due to the late arrival of the transport infrastructure problems.

In case of fire in the 106-meter 32-storey "Vidzor Building" office building in Madrid in 2005 , the staff tried to put out the fire yourself, causing firefighters arrived at the scene just over two hours. The fire spread from the 1 st to the 32 th floor.

The building was provided by the central reinforced concrete core and steel outer frame, which is a result of a fire struck the 6 upper floors (Fig. 1b), subsequently decided to demolish the building was [31]. This fire was the main discussion example destruction of bearing structures of the building up to the tragedy of the World Trade Center (WTC, World Trade Centre) September 11, 2001 in New York, the United States, which killed 2,451 people, and damage amounted to $\$ 33.4$ billion [32 - 37].

The collapse of the WTC buildings - the first case of complete destruction of the highrise building. The report National Institute of Standards and Technology (USA) [39] according to the analysis emphasized the importance of adequate fire protection. The main idea of the recommendations was binding regulatory requirements for the design basis 
threat. The recommendations, which were presented at the NIST report, are reflected in the annex to the US national standards.

After the tragedy of September 11, many standards have been revised on the basis of this report. As previously occurred fires in high-rise buildings do not lead to the complete destruction of the buildings, some of the rules in different countries allow the evacuation plan with only the fire floor and adjacent floors above and below. Who is considered the evacuation, including, if possible, the whole building [39].

Fire Spread height of the building, as opposed to the spread of fire in the horizontal direction due to the need to overcome the fire building slabs, each of which is fire-resistant. Thus in the ceiling, in contrast to the walls and partitions, no doorways and windows. Protecting designs of staircases, lift shafts and ducts crossing the building vertically, also performed fireproof. It is clear that the division of the building into fire compartments in the vertical is in this case purely nominal.

The spread of fire on high-rise buildings with the most serious consequences, as a rule, takes place on the facades. A typical example is a fire in a government 32-storey skyscraper "Transport Tower" in the Kazakh capital Astana, 30 May 2006 (Figure 1, a)). Flames destroyed facing about 15 floors on one side of the building and all the 32 floor to another. The fire was accompanied by the dispersion of shards of glass façade [40].

a)

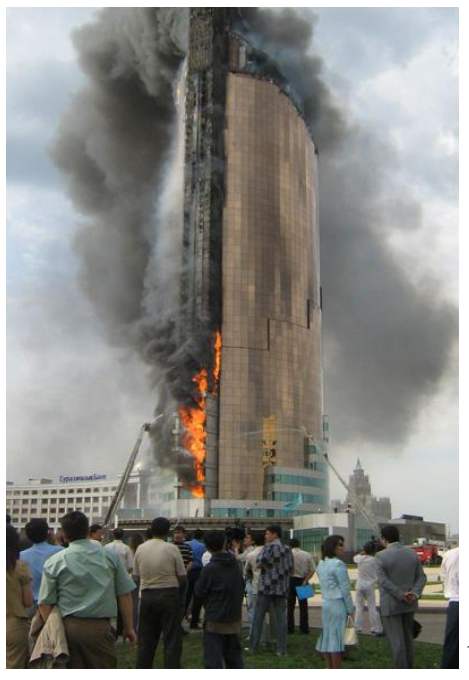

b)

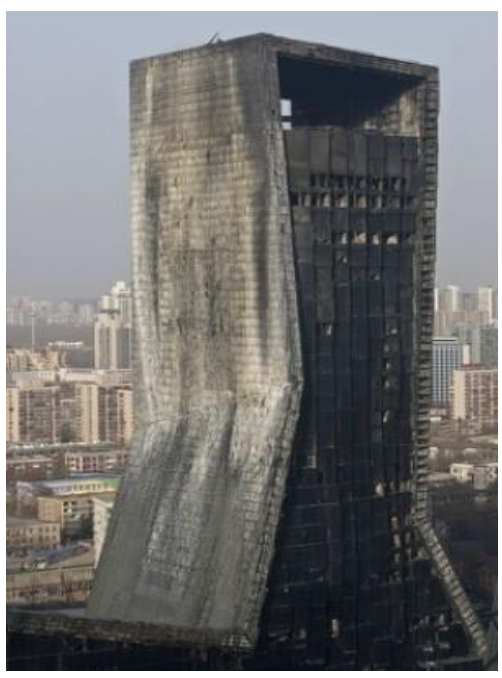

Fig. 1. a) Fire in skyscraper «Transport-Tower», Astana; b) Hotel Mandarin Oriental after fire, Beijing

In case of fire in the 159-meter 44-story Mandarin Oriental hotel building in Beijing February 9, 2009 (Figure 1, b)), the fire quickly spread down the facade. The fire lasted for about 5 hours. During this time, approximately $80 \%$ of building burnt. In fire fighting involved about 600 firefighters. Due to the severe fire in the city fell ashy snow, which happens on volcanic eruption. The fire is called the fireworks, the remains of which firefighters discovered on the roof of the building. According to various estimates prior to the fire, 65 people were - the hotel staff. 5-star hotel with 241 rooms did not have time to put into operation. The total investment in its construction amounted to $\$ 700$ million [41]. 
a)

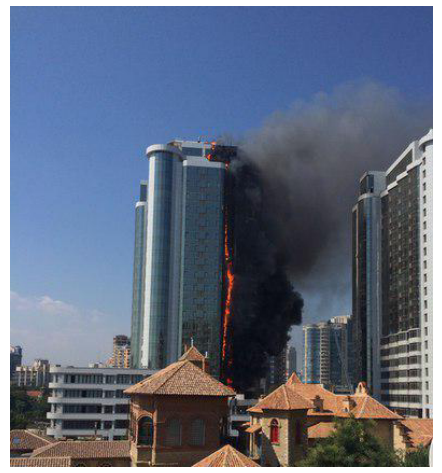

b)

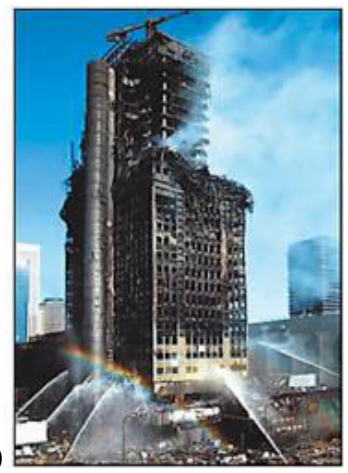

Fig. 2. a) Burning high-rise 24-storey building in Odessa; b) The fire in the 32-storey skyscraper, Madrid

In conventional buildings, in the absence of horizontal barriers in the facade, the flames from the window opening 15-20 minutes from the start of a fire in a room can spread up the balconies, loggias, window frames, igniting flammable building elements and furnishings in floor space located above .

In high-rise buildings are widely used ventilated facade systems. In some types of facade used combustible materials and as a supporting framework used aluminum profiles, which considerably increases the class of constructive fire danger buildings. The use of easily flammable insulation (thermal insulation) can lead to the rapid spread of the fire and the formation of highly toxic combustion products, as evidenced by the above example. The use of such materials should be limited to the development of high-rise buildings requirements.

There are two principles of valuation fire compartments: they allowed the area and functional characteristics $[5,6,8,9,20,22,31,33$ - 37].

However, in the fire compartment can be placed several functional processes, different in purpose and fire hazard. Fire resistance is an international fire-technical characteristic, which regulated building codes and regulations, and describes the ability of structures to resist the action of fire. Measuring fire resistance parameters standardized international norms and standards in different countries, based on the standard ISO 834-11:2014 [42] which is designed to cover a range of thicknesses of the fire protection material, a range of steel sections characterized by their section factors, a range of design temperatures, and a range of valid fire resistance classification periods. In this regard, the fire resistance is a basic element of the whole system of fire protection of buildings, as is the decisive parameter for selecting other security features.

\section{Discussion}

Since the phenomenon of progressive collapse is probabilistic in nature, completely eliminate the risk of its occurrence is impossible, but with prior calculation and circuit simulation collapse due to fire damage can be minimized in the local destruction and to provide the necessary time to evacuate people in the building.

Resistance to progressive collapse due to fire means that in case of fire in high-rise buildings allowed local caving individual vertical bearing elements within a floor or areas overlap one floor, but the initial collapse should not cause the destruction of structures that are transmitted load before seen elements damaged emergency impact [1].

As a local collapse, understand:

- vertical structures one floor house a limited area of around $80 \mathrm{~m}^{2}$ (diameter $10 \mathrm{~m}$ ): 
- two walls intersect, in areas of their place of intersection of the nearest hole in each wall or to the next vertical cross section of the wall the other direction;

- separate columns from the surrounding areas of walls located on one floor in the area of local caving;

- areas overlap one floor to collapse the local area.

In all cases, the total cross-sectional area remote vertical elements, located on a plot of $80 \mathrm{~m}^{2}$, should not exceed: for concrete elements $0,9 \mathrm{~m}^{2}$ for fiber concretes elements $0,7 \mathrm{~m}^{2}$ for tough fixtures $15 \%$ [1].

The most dangerous fire to the upper floors, water pump not enough power, not enough fire ladder length.

Multifunctional buildings height over 16 floors should have a special degree of fire resistance. According to the fire resistance of buildings over 16 floors height, special requirements towards their increase [2], for example:

- constructions of these buildings should be made of non-combustible materials.

- minimum fire resistance of structures multipurpose buildings increased storey with a special degree of fire resistance shall be not less than: load-bearing walls - REI 180 fire walls - REI 180 columns - R180, wall stairwells - REI 180 items beams (beams, girders, frames, trusses) - R 180180 -REI fire floor, elevator shafts envelope - REI 90 fire pits envelope elevators - REI 120 communication envelope mines - REI 60, etc.

The average fire load of these buildings do not exceed $50 \mathrm{~kg} / \mathrm{m} 2$ (in terms of wood).

For high buildings over 100 meters above limit fire main structures is recommended to increase by 1 hour.

This requirement seems excessive, leading to a rise in construction, difficulties in the design of ultra-high buildings.

Effectively the requirement to use during building construction designs that with standard fire resistance testing should resist temperatures up to $1100^{\circ} \mathrm{C}$ for 4 hours. This corresponds to the fire load in the room in terms of wood, $150 \mathrm{~kg} / \mathrm{m} 2$, exceeding actual and permissible fire load value in areas of tall buildings in 2 times. For example, two 110 -storey office buildings of the World Trade Center in New York City fire load in the office during the events of September 11, 2001 was $40 \mathrm{~kg} / \mathrm{m} 2$ equivalent timber and according to regulations of Ukraine, allowed fire loads in areas of tall buildings do not exceed $50 \mathrm{~kg} / \mathrm{m} 2$. Because of this, it is possible to limit norms for maximum fire resistance of structures tall buildings the size of 180 minutes ( 3 hours).

The special nature of the fire danger high-rise buildings is determined by:

- presence of conditions conducive to the emergence of a fire;

- possibility occupancy in the building;

- height of the building, exceeding the possibilities of using to save people mechanical stairs that are in the fire service garrisons;

- possibility of partial or complete destruction by fire of individual elements of the building, some parts of the building or the entire building;

- widely adopted in high-rise building flame, smoke, toxic substances on the premises, corridors and technical communications, and through gaps in building constructions;

- blocking lifts and failure of control elevators;

- lack or insufficiency of resources and time to rescue people in the middle of the building;

- lack of clear rules in the regulations on the assessment of fire danger analyzed objects.

Fire protection systems height of buildings above 16 floors and includes 15 security features that are intended can be grouped into the following components [2]:

Block 1. Measures to ensure the sustainability of buildings or parts thereof against progressive collapse:

- providing fire resistance of structures and buildings; 
- ensuring explosion building, which can be explosive premises.

It should be noted the particular importance of this unit measures of fire protection system for high-rise buildings, as it provides a "primary safety" object in the form of reserve stability of the system, its ability to resist over time not only the impact of the fire, but others, including combined influences. If the object has insufficient stability of the entire system to ensure the safety of people and buildings in general becomes useless.

At high temperatures that occur during fires reduced strength overlap and they can collapse. The collapse could happen after the fire, because after lowering the temperature toughness ceiling is not restored. Cover also collapses due to accumulation of water on them, which poured fire.

So, for backup strength and stability of buildings against progressive collapse, its constructive scheme should include reserve items. These elements can be diaphragm stiffness, columns, autryherni floors, which in case of fire can perform additional functions redistribution of loads.

High buildings should be calculated using software systems that allow you to take into account the physical and geometric nonlinearity follows [7]:

1. A calculation of all circuits in physically nonlinear statement on permanent and temporary load that are emergency communications. The resulting stress strain state is starting to calculate the load of elements removed.

2. Calculation of the additional load of items that are removed conducted in physically and geometrically nonlinear statement. Loads of removing items correspond to the obtained them at the preliminary stage of calculation and increased by a factor of 1.2 dynamism. Test of strength elements remaining performed excluding buckling. The calculation also need to perform physically and geometrically nonlinear statement. If it appears that some elements of the model are not satisfying strength (destroyed), the calculation goes the same way for the next step without such elements.

3. Every floor high-rise buildings should be calculated on the weight of perception overlap areas top floor (permanent and long loads with dynamic coefficient $=1.5$ ) over an area of $80 \mathrm{~m} 2$.

4. The calculation will be completed or localized progressive damage or complete destruction of the settlement scheme.

This simulation of force majeure can detect additional, backup, load-bearing capabilities are primarily associated with the effect of adaptability. For example, floor-designed for large troughs starts as membrane and objectives Designer ensure such work [3].

Block 2. Measures to limit the spread of fires in high-rise buildings:

- unit fire barriers in the middle of the building;

- placement of fire breaks between buildings.

Block 3. Measures to ensure timely and unimpeded evacuation and rescue them at HB in high-rise buildings. The main provisions of the regulations on the safety of people at fires in buildings are the requirements provided in case of fire:

- the possibility of evacuation of people, regardless of age and physical condition before the threat to their life and health;

- access personnel fire departments and fire fighting to feed the fire, and interventions to save lives and property.

The solution to this problem in the design of new and renovated buildings implemented the following measures:

- measures for timely evacuation and protection against smoky;

- fire alarm systems and evacuation management;

- measures to save lives and limit the fire risk of materials, structures and buildings.

Block 4. Active Protection System buildings from fire:

- fire alarm system and fire fighting; 
- stronghold of the fire;

- Central device remote control system of fire protection building.

\section{Conclusions}

Thus, conclude that resistance to progressive collapse in fires serves:

- margin basic building structures that should provide most profitable way: rational design and planning solutions building, structural measures to ensure the integrity of the construction, use of materials and design solutions that ensure development in structural elements and their compounds plastic deformation, designing technical floors in a spatial system, etc.

- use of 4 units of fire protection systems.

- preservation of fire resistance of the main load-bearing structures with the free development of fire;

- exception progressive collapse with loss of fire resistance of individual bearing structures.

- division into fire compartments tall building height does not solve the problem of limiting the spread of fire and height of the building can be replaced by a zoning technical systems. Efforts should be focused on limiting the spread of fire on the facade.

\section{References}

1. DBN V.2.2-15-2005

2. DBN V.1.1.-7-2002

3. DBN V.1.2-2: 2006

4. NFPA 5000, Building Construction and Safety Code

5. International Building Code 2009, International Code Council, Inc., USA (2009)

6. PD7974-6: The application of fire safety engineering principles to fire safety design of buildings, Human factors: life safety strategies - occupant evacuation, behaviour and condition (British Standards Institution, London, 2004)

7. V.M. Pershakov, M.S. Barabash, A.O. Bielyatynskyi, K.M. Lysnytska, Problems countering progressive collapse of structures of buildings (NAU, Kyiv, 2015)

8. B. Stafford Smith, A. Coull, Tall building structures: analysis and design (John Wiley \& Sons. Inc., USA, 1991)

9. U.S. Fire Administration, Highrise Fires, Topical fire research series, 2(18) (2002).

10. C. H. Chen, Y. F. Zhu, Y. Yao, Y. Huang, X. Long, Journal of Constructional Steel Research. 122, 238-250 (2016)

11. B.A. Izzuddin, A.G. Vlassis, A.Y. Elghazouli, D.A. Nethercot, Engineering Structures, 30(5), 1308-1318 (2008)

12. A.G.Vlassis, B.A.Izzudin, A.Y.Elghazouli, D.A.Nethercot, Engineering Structures, 30(5), 1424-1438 (2008)

13. M.A Qian-li, Huang Ting-lin, Procedia Engineering, 11, 302-307 (2011)

14. P. Kolarkar, M. Mahendran, Fire Saf. J., 53, 85-104 (2012)

15. M. Lazarevska, M., Cvetkovska, M., Knezevic, V. Murgul, N. Vatin, Applied Mechanics and Materials, 627, 276-282 (2014)

16. N. Vatin, A. Sinelnikov, M. Garifullin, D. Trubina, AMM, 1037-1041, 633-634 (2014)

17. G. Craighead, Butterworth-Heinemann, 3, 39-43 (2009)

18. M. Jocovic, B. Melovic, N. Vatin, V. Murgul, Applied Mechanics and Materials, 678, 644-647 (2014) 
19. L. Huanga, T. Chen, H. Yuan, Transportation Research Procedia, 2, 518 - 523 (2014)

20. V.A. Macovei, Journal Emergencies. Industrial and environmental safety, 12, 28-36 (2015)

21. J. Jianga , L. Chenb, S. Jiangc , G.-Q. Lic, Case Studies in Fire Safety, 4, 28-38 (2015)

22. Ahmad, S.A. Hassan, A. Ripin, M. W. Ali, S. Haron, Fire Safety Journal, 58, 160-169 (2013)

23. O. A. Mohamed, Structural Engineering, 3, 11-18 (2015)

24. S. Elkoly, B.E. Ariss, Engineering Failure Analysis, 40, 33-47 (2014)

25. J. Li, H. Hao, Engineering Structures, 52, 101-113 (2013)

26. K. Mela, T. Tiainen, M. Heinisuo, Advanced Engineering Informatics, 26(4), 716-726 (2012)

27. M. Salminen, M. Heinisuo, Journal of Constructional Steel Research, 97, 105-113 (2014)

28. R. W. Archibald, J. J. Medby, B. Rosen, J. Schachter, Security and Safety in Los Angeles High-Rise Buildings After 9/11, (RAND, USA, 2002)

29. Information on: http://911 research.wtc7.net/wtc/analysis/compare/fires.html

30. Information on: http://odpublic.net/news/2015/08/29/v-arkadii-gorit-vysotka/

31. R. Pope, New Steel Construction, 14(3), 26-8 (2006)

32. G. Roger Morse, Fire Engineering, 10, 45-53 (2002)

33. V.M. Roitman, Global Security, 9, 30-35 (2006)

34. M. Gravit, A. Vaititckii, M. Imasheva, D. Nigmatullina, A. Shpakova, Classification of fire-technical characteristic of roofing materials in European and Russian regulation documents, MATEC Web of Conferences 53, 01031 (2016)

35. A. Krivtcov, M. Gravit, S. Zimin, O. Nedryshkin, V. Pershakov, Calculation of limits of fire resistance for structures with fire retardant coating, MATEC Web of Conferences 53, 01032 (2016)

36. L. Svatovskaya, A. Sychova, M. Sychov, V. Okrepilov, MATEC Web of Conferences, 53, Article Number 01023 (2016)

37. M. Gravit, V. Gumenyuk, M. Sychov, O. Nedryshkin, Estimation of the pores dimensions of intumescent coatings for increase the fire resistance of building structures, Procedia Engineering, 117, 119 - 125 (2015)

38. N.C. McConnell, K.E. Boyce, J. Shields, E.R. Galea, R.C. Day, L.M. Hulse, Fire Safety Journal. 45, 1-34 (2010)

39. Federal Building and Fire Safety Investigation of the Word Trade Center Disaster: Final Report of the National Construction Safety Team on the Collapses of the World Trade Center Towers. NIST NCSTAR 1, (National Institute of Standards and Technology, Gaithersburg, MD, 2005)

40. Information on: http://www.newsru.com/world/30may2006/tower.html

41. Information on: http://911 research.wtc7.net/wtc/analysis/compare/fires.html

42. ISO 834-11:2014. Fire resistance tests -- Elements of building construction - Part 11: Specific requirements for the assessment of fire protection to structural steel elements. 